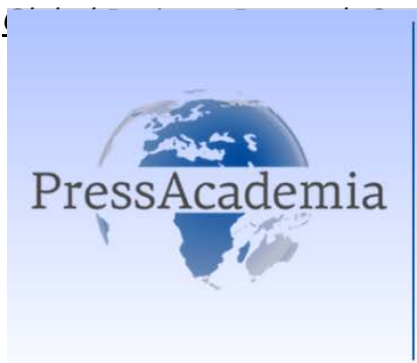

Press Academía

Procedía

Global Business ResearchCongress (GBRC), May 26-27, 2016, Istanbul, Turkey.

\title{
THE ROLE OF WOMEN ON THE OTTOMAN ECONOMICS
}

\section{DOI: 10.17261/Pressacademia.2016118633}

\section{Nurullah Karta}

Yüzüncü Yıl Üniversitesi. nkarta25@gmail.com

\begin{abstract}
There is no sifficient Research was conducted on the participation of women on the Ottomon Economic system. Most of the time, women in Ottoman State described from the framework of harem. However, truth is very different. The role of the women is significant in economic activities. The Ottoman women was participated in economic and social issues very actively. In the classical era of Ottoman State, participation of women was weaker than men in the areas of social, economic, and political life. The role of women especially in the area of education is significant. The participation of women in working life is much more than thought. As a dominant economic sector, women heavily participated in agriculture and have bigger role in it. People in Anatolia as general, and women and children as special were spent time in agriculture, animal husbantry. In peace time or war time women lead the economic affairs. Women worked in textile industry, home economics according to archive documents. In the West, first time women worked for somewhere else for a certain wage in the industry era in England. In the beginning of 19th century in West, women started to work in textile and production sectors. Women started to work after Tanzimat in service and production sectors in Ottoman State. Furthermore, there are examples that women in Anatolia engaged in shopping, and opened stores. For example, silk production facilities in Bursa was owned heavily by women. Also, most of the workers were muslim and nonmuslim women. There were also baker women. This study, the role of the women in Ottoman State is studied acccording to the Archives of Ottomon of Prime Ministry.
\end{abstract}

Keywords: Ottoman, women, economy, shopping, heritage.

JEL Codes : B16, N10, Y10

\section{OSMANLI EKONOMISINDE KADININ ROLÜ}

\section{ÖZET}

Osmanlı ekonomisinde kadının rolü ve çalışma hayatına katılmasına yönelik yapılan araştırmalar yeterli düzeyde değildir. Özellikle Osmanlı kadını haremin çerçevesinden bakılarak tanımlanmaktadır. Ancak gerçeklerin çok farklı olduğu Osmanlı arşiv vesikaları incelendiğinde Osmanlı kadınının aile ve toplum hayatına önemli ölçüde ekonomik katkıları olduğu görülmektedir. Osmanlı İmparatorluğunun klasik döneminde toplumsal, ekonomik ve politik yaşam konusunda, kadınlara tanınan rol erkeklere oranla daha sınırıdır. Osmanlı toplumsal yaşamında kadınların halkın geçimi ve eğitimi için yaptıkları katkıları, çalışma yaşamında etki ve rolleri ise düşünülenden çok daha fazla olmuştur. Osmanlı’da hakim sektör olan tarımda kadının ağırıklı bir rolü olmuştur. Anadolu halkının kadın ve çocuklar olmak üzere tarım ve hayvancılıkla uğraştığını, barışta olsun, savaşta olsun, kadının ekonomiye yön verdiğini, ev endüstrisinde tekstil üreticiliği, ipek böcekçiliği dokumacılı̆̆ı ile uğraştığıı belgelerle tespit edilebilmektedir. Batı'da ilk kez sanayi devrimi sonrası İngiltere'de kadınlar ücret olarak ifade edilen ekonomik bir gelir karşılığı bir başkasının hesabına çalışmaya başladığı görülmektedir. 19. Yüzyııı başlarında imalat, dokuma sektöründe kadınlar ağırıklı olarak görev almışlardır. Osmanlıda ise Tanzimat sonrası kadınlar sanayide ve hizmet sektörlerinde iş̧i olarak çalışmaya başlamışlardır. Ayrıca Anadolu kadınının ticaretle uğraştığını, ticarethane açtığıı gösteren çeşitli örnekler mevcuttur. Örneğin Bursa'da iplik eğirme atölyesinin yarııından fazlası kadınlara aittir. Bursa fabrikalarındaki işçilerin çoğu Müslim ve gayrimüslim kadınlardır. Evinde dokuma ve işleme yapan kadınların yanı sıra, değirmen ve fırın sahibi kadınlar da bulunmaktadır. Bu çalışma, Başbakanlık Osmanlı Arşivinde tespit edilen belgelerden hareketle Osmanlı kadının toplum hayatında ekonomik rolü, mal sahibi olabilme ve miras alma-bırakma, ticaret yapma ve üretime katılma konular üzerinde durmayı amaçlamaktadır.

Anahtar Kelimeler: Osmanlı, kadın, economi, ticaret, miras.

JEL Kodları : B16, N10, Y10 


\section{GíRiş}

Osmanlı Devleti'nin toplumsal yapısı, içtimai ve iktisadi hayatı, ahalinin gelir düzeyleri, sosyal ilişkileri ve hayat tarzları tespit etmek üzere pek çok çalışma yapılmıştır. Bu bağlamda üç kıtaya yayılmış olan ve altı yüzyılı aşkın bir süre varlığını sürdürmüş farklı etnik ve dini kimliğe mensup toplulukları bir arada yaşatma becerisini gösteren Osmanlı Devleti'nin sosyal, kültürel ve ekonomik yapılanmasında erkekler kadar kadınlarda söz sahibi idi.

Osmanlı toplumunda kadının özellikle ekonomiye katkısı hakkında yapılan bazı araştırmalarda, Kadınların çalışma hayatında Tanzimat Fermanı'na kadar aktif olarak yer almadığı ileri sürmektedir. Temel bakış açısı, bazı oryantalist söylem çerçevesinde oluşturulmaktadır. Kaleme alınan ifadeler olumsuz imajların tekrar edilmesinden ibarettir. Osmanlı kadınlarını tasvir eden kimi Batılı seyyahlarda; Z.DuckettFeriman, Miss Julia Pardoe, Lady W.M. Ramsey, LadyMontague ve M. De M. D'Ohsson gibi yazarlar eserlerinde Müslüman kadını olumsuz imajlarla tasvir ederken, satır aralarında Osmanlı toplumunda Kadının konumu, Batı toplumlarına göre çok daha iyi yerde oldukları gerçeğine işaret etmekten de kaçınmamışlardır. Azda olsa rasyonel davrandıkları söylenebilir (Sancar, 2010: 24-27).

Osmanlı devlet yönetiminin temel dayanağı İslam hukuku idi. Bu bakımdan İslam dinine göre, kadın mal sahibi olabilmekte, ticari sözleşmelere imza atabilmekte idi. Haliyle İslam'da kadın velâyet altında değildi. Hakları aynı zamanda mahkemeler yoluyla korunuyordu (Baş, 2006:67).Bu anlamda kadınların ekonomik faaliyetlerine yönelik kısıtlayııı bir engel söz konusu değildi. Nitekim Müslüman kadınların ekonomik faaliyetlerde bulunması yönünde İslam tarihinden örnekler bulmak mümkündür(Ecer, 2012; Köksal, 2010).

Tarihin her döneminde, dünyanın hemen hemen her ülkesinde nüfusun önemli bir kısmını oluşturan kadınlar emek yönüyle vazgeçilmez bir üretim unsuru olmalarına rağmen emek piyasalarındaki varlıkları ve katkıları gerek geçmişte, gerekse günümüzde hak ettikleri yerde değildir. Cinsiyete dayanan iş bölümü her toplumda farklı düzeyler de olsa da temelde; çocuk doğurmak ve büyütmek, ev işlerini yapmak gibi işler fizyolojik ve sosyolojik acılardan kadınların temel görevleri arasında yer alırken, piyasada çalışarak para kazanma işi erkeklerin esas görevi gibi görülmüştür (Özer, M.,Biçerli, K. 2004 :55-85). Oysa; kadın biyolojik hayatın olduğu kadar sosyal ve toplumsal yaşamın da en temel unsurlarındandır. Kadınlarımız toplum hayatının şekillenmesinde tartışılmaz yere sahiptir. Müslüman Türk kadını ilk dönemlerden itibaren ekonomik faaliyetler içerisinde erkeklerle birlikte etkili olduğu bilinmektedir. Hem şehir hayatında hem de kırsal hayatta üzerine düşen sorumluluğu fazlasıyla yerine getirmişlerdir.

Çalışmamızda Başbakanlık Osmanlı Arşivi belgelerinden istifade edilerek, Osmanlı toplumunda Müslüman kadınların mal varıklarını ve bu mallarını nasıl idare ettikleri, ne gibi ekonomik ilişkilere girdikleri, hangi meslekleri icra ettikleri üzerinde durulacaktır.

\section{LITERATÜR TARAMASI}

\subsection{Genel Olarak Osmanlı Kadını}

Osmanlı toplumunda kadınların ekonomik hayata dair verimliliği (prodüktivite) erkekler tarafından kimi kez perdelense de, Osmanlı kadınlarının mülkiyet hakkına sahip olduklarından dolayı, çağdaşı pek çok kadının aksine, geleneksel aile ekonomisine katkı sağladıkları, aktif olarak yer aldıkları ticaretle uğraştıkları yapılan bazı çalışmalarla ortaya konulmuştur. (Jennings,1975;Gerber,1980).

16. Yüzyıl Osmanlı toplumunda ekonomi esas olarak tarımsal faaliyetlere dayanıyordu. Nüfusu yaklaşık olarak \%90'ı kırsal alanlarda yaşamaktaydı. Bu kırsal nüfusun büyük bir bölümü devlet maliyetindeki toraklar üzerinde ve aile işletmeleri çerçevesinde tarımla uğraşmaktaydı. İşledikleri toprak miktarı ve sağladıkları gelir açısından kırsal kesim üreticileri arasında önemli bir ekonomik farklılaşma görülmüyordu. Kırsal nüfus tükettikleri giyim eşyaları ve basit üretim araçları gibi tarım dışı malların önemli bir bölümünü erkek kadın birlikte kendileri üretmekteydi. Osmanlıda nüfusun yaklaşık olarak \% 10 'uda kentlerde oturmakta ve esnaf loncalarına bağıı olarak zanaatlarla ve diğer tarım dışı faaliyetlerle uğraşmaktaydı (Pamuk, 1990:32). Ancak şehirlerde yaşayan kadınlar birazdan ele alacağımız üzere esnaf loncalarına kabul edilmeksizin zorda olsa çeşitli meslekleri icra etmeyi başarmışlardır. 
Osmanlı toplumunda özellikle kırsalda tarım ve hayvancılık konusunda erkek ve kadınlar arasında geleneklere dayalı bir iş bölümü olduğunu açıktır. Bu tarımsal iş bölümünde erkekler genellikle tarımsal işlerin bir kısmını yerine getirirken, kadınlar hem yeniden üretim, hem de ailenin yaşamının sürdürülmesi için gerekli tüm intiyaçları karşılamaya yönelik faaliyetleri de gerçekleştirirler. Bunun yanı sıra gıda seçimi, üretimi, yetiştirilmesi, hazırlanması ve hasadında merkezi role sahip olmaları, tohumları saklayıp korumaları, hayvan üretimi ve ıslahına ilişkin bilgilere sahip olmaları nedeniyle kadınlar tarımsal üretimi geliştirdikleri gibi çeşitlenmesine de vesile olmuşlardır. (Aysu, 2009). Dolayısıyla kırsalda kadınların hane ekonomisinde daha etkili oldukları gözlenmektedir. Devletin mali ekonomisinin temeli tımar sistemi, çift-hane üzerine kuruluydu (İnalcık, 1998). Hane evlenmiş erkeğin, eşi ve çocuklarıyla oluşturduğu küçük birüretim birimi olarak algılanmaktaydı ve sermayesi toprak olan hane sahibi üretiminsürekliliğini sağlamak durumundaydı. Bu açıdan aile üretim açısından önemliydi.

Başbakanlı Osmanlı Arşivinde kayıtlı bulunan Tahrir defterlerinde ${ }^{1}$ (BOA.TD.149:257-342; BOA.TD.232:287383)Rumeli ve Anadolu'da kadın ile ilgili olarak, bir şekilde eşini kaybeden ve bu nedenle ailenin ekonomik sorumluluklarını üstlenmek durumunda kalan "bive" olarak tabir edilendul kadınların kayıtlarına da rastlanılmaktadır. Osmanlı şehir ve kazalarını ve buralara bağlı köyleri kapsayan, vergi vermekle mükellef reayanın kayıtlarının tutulduğu bu defterlerde kadınlar toprağı işletip vergilerini ödedikleri sürece toprakları ellerinden alınmazdı (Inalcık ve Quataert, 1994 : 148).

Osmanlı Devleti timar uygulamasında yukarıda da dile getirildiği gibi çift-hane sitemine göre vergi veren reayayı kayıt altına almıştır. Kadın ve çocukların varlığı kayıtlara yansımasa da genel kabul gören Osmanlı ailesi bir hane 5 kişiden (Barkan, 1953 : 1-26) müteşekkildir esasına göre kadın ve çocuklarda dahil edilmiş oluyor. Tahrir kayıtlarında adı vergiye tabi olanlar dışında doğrudan yer almasa da kadınsız bir toplum düşünülemez. Osmanlı toplumunda özellikle kırsalda kadının ekonomik katkısı düşünülenden de fazla olduğu açıktır.

Köy hayatında tarım ve hayvancılı̆ın önemli yer teşkil etmesi, üretim bakımından kadını öne çıkarmaktadır. Burada vurgulanması gereken geleneksel yöntemlerle yapılan tarım ve hayvancılık, kadının bu hayata entegre olması şehir yaşamına göre daha kolaydır. Bu anlamda kırsal alanda yasayan kadın hayatın zorluklarına ve yasam standardı şehirli kadına göre daha düşüktür denilebilir. Ancak, şehirli kadına göre sosyal yasamı daha özgür ve ekonomik rolü bakımından ailede konumu daha güçlüdür (Dingeç, 2010 :13).Müslüman Osmanlı kadını sosyal ve iktisadî hayatın bir parçası haline gelmesinde her hangi bir rahatsızlık söz konusu değildir. Bilhassa taşra kesimindeki kadınlar tarım, el sanatları ve atölyelerde üretime aktif olarak katılmışlardır. Dolayısıyla, Osmanlı'da kadınlar İslam Hukuku'nun kendisine sağladığı miras ve mehir alma haklarını kullanarak mal sahibi olabilme ve tasarruf etme haklarına sahiptiler. Kadın evlenmesi durumunda bu hakkını kaybetmediği gibi, evlilikte eşler arasında mal ayrılığı ilkesi olması sebebi ile kadın İslam'ın kendisine sağladığı bu haklarını kullanabiliyordu. Osmanlı Devleti'nde kadın, sahip olduğu ekonomik varlığıyla çeşitli ticârî anlaşmalara da taraf olmuştur (Baş, 2006 :6). Kadının tam eda ehliyeti varsa (mümeyyiz, baliğ, reşit) kimsenin rızasına ihtiyaç olmaksızın malları üzerinde ivazlı-ivazsız her türlü tasarrufta bulunabilir (Akyılmaz, 2002 :368).

\subsection{Ticari Alanda Osmanlı Kadını}

Tarihsel olarak ticaretin artması ve ticari çıkarların öncelik kazanmaları piyasa düzeninin kurulmasını öngörmüştür. Çeşitli kurum ve kurallardan meydana gelen bu düzen ise her toplumun kendine özgü siyasetleri, çıkar ilişkileri ve çatışmaları tarafından belirlenmiştir (i̇slamoğlu, 2010 :62). Dolayısıyla ticaretin ve bunun piyasasını oluşturanların cinsiyeti pekte öne çıkmaz. Ancak çalışmamızda kadının ekonomik rolü hedeflendiği için pozitif bir yaklaşımla sadece kadın üzerinden hareket edilecektir.

Osmanlı toplumunda kadının ticari hayata katılması uygulamalara bakıldığında çok sayıda örneklerle doludur. Bursa'da Emlak alımı ile ilgili Kadınlar kocalarına mülk alım-satımı yapmışlardır (Gerber, 1998 : 330). Trabzon, Amasya, Karaman kadı sicillerinde ise yüz elli dört mülk devrinin yüzde otuz altısında kadın adına rastlanmaktadır. (Baş, 2006: 69). íktisadi ilişkilerinde önemli bir yeri olan borç alış verişlerinde erkeklerin olduğu kadar kadınların da yer aldığını ve bilhassa borç veren kadınların oldukça fazla olduğunu gösteren belgeler mevcuttur (Koca, 1998 : 90). 18. Yüzyıla ait belgelerde (BOA, Cevdet, Maliye, nr. 18496; Cevdet Adliye, nr. 1873;

\footnotetext{
${ }^{1}$ Belgenin kısaltılmış şekli BOA (Başbakanlık Osmanlı Arşivi), Tahrir Defteri (TD).
} 
Cevdet, Maliye, nr. 21350; Cevdet, Maliye, nr. 11427; Baş, 2006).iki hanım kocalarından ev, bir hanım babasından yirmi dokuz adet dükkân, bir kahvehâne ve arsaları ile beraber zeytin ağaçlarını, iki hanım da devletten ev satın aldıkları kayıtıdır.

Bir başka belgede de (Şer'iye Sicilleri, I ve II, Türk Dünyası Araştırmaları Vakfı, İstanbul, 1989, cilt:2; naklen Koca, 1998:38) şehirdeki mülk bahçesini Sefer kızı Fatma'ya satan Süleyman kızı Saliha'nın mülk alım-satımına ilişkin “Hacı Murat Bey mahallesinde, bir tarafı Ahmet Bey oğlu Mehmet Çelebi mülkü, bir tarafı Kasım Çavuş Bey'in mülkü ve iki tarafı a umumi yol ile sınırlı olan, su kuyusu meyveli meyvesiz ağaçları bulunan mülk bağı, bundan kısa zaman önce vefat eden kocam Malkoç Bey hayatında ve sıhhatli halinde bana şer'i ve geçerli bir bağışlama akdiyle temlik etmiş ve ben de bu bağışlamayı kabul ederek akit konusu malı teslim almıştım. Bu ana kadar tasarruf ettiğim ve vasıfları yukarıda zikredilen bağı, Hüseyin Çelebi'ye 8000 Osmanlı akçesine meşru ve geçerli bir satım akdi ile sattım ve teslim aldım. Alıcı Hüseyin Çelebi de zikredildiği şekilde satın aldı, semeni olan 8 bin akçeyi de kendisinden bizzat tam olarak teslim aldım. Bundan sonra zikri geçen bağ, alıcı Hüseyin Çelebi’nin mutlak mülküdür, dilediği şekilde tasarruf etsin" denilmektedir. Belgeden de anlaşılacağı üzere şehirli kadınlar mülk arazilerinin gelirlerini değerlendirmeye çalışmışlardır.

Bu açıdan kadınların mülk sahibi olabilme hakkı ve bu mülklerini tasarruf etme hürriyeti onların iktisadi hayatta iş yapabilme kabiliyetlerini geliştirmiştir. Ancak yine de şehirli kadınların işlerini vekillerine havale etmeyi tercih ettiklerini görülmektedir (Koca, 1998:91). Bu tercih Osmanlı toplumunun geleneksel anlayışına bağlanabilir. Köylerde kadınları adına kayıtlı geniş mülkler, araziler söz konusu değildir. Kadınlar, Osmanlı Devleti'nin kuruluş dönemlerinden itibaren arz-talep çerçevesinde ekonomik girişimlerde bulunmuştur. Kırsal alanda erkeği ile birlikte tarım ve hayvancılık alanında üretime katkıda bulunurken şehirde de imalat ve hizmet sektöründe yer almıştır. Kadın, dokuma tezgâhında, çeşitli kumaşlar dokumakta, ip eğirmekte, mum imal edip satabilmekteydi.(Dingeç, $2010: 17)$.

Bir reaya ailesi hane halkının, kullanım değeri için üretim yapmakta, hatta devlete vergisini bile aynı olarak ödemektedir. Kadın, kırsal kesimde işgücü bakımından öne çıksa da kadınlar üzerine kayıtlı araziler sınırlıdır. Bu bakımdan kadınların alım satım işlemlerinin ekonomik etkileri konusunda genellemeler yapmak mümkün olmasa da köy ile şehir arasında iktisadi faaliyetlerde mükemmel bir organizasyondan söz edilebilir (Koca,1998:89).

Müslüman kadının Özellikle tüccar bir aileye mensup olması işini kolaylaştırmıştır.1600 ve 1625 yılları arasında kumaş dokuma ve deri işlemede öne çıkan Kayseri kadı sicillerinin incelenmesiyle, çok sayıda kadının toprak sahibi, üretici ve zanaatkâr olarak ekonomik faaliyet içerisinde oldukları göstermektedir (Oktar, 1998:24). Ekonomik bağımsızlığını kullanmada Müslüman kadın, İslam Hukukuna göre mal edinme ve tasarruf etme hakkı kendisinde olmasına rağmen yine de belli ölçülerde erkeklerle mücadele etmek durumunda kalmıştır. Varlık durumlarına göre dokuma tezgahı, dükkan, değirmen, fırın işleten, şehirli kadınlar kısmen kırsal kesimde yaşayan kadınlara göre daha fazla tüketici konumundadır. Kırsalda ise üretim ve tüketimin temelini oluşturan aile önceden de ifade edildiği gibi hane emek birimine dayanmaktadır. Aile içerisinde erkek kadın ayrımı olmaksızın mal ve üretim ortaklaşa yapılmaktaydı. 1567'de Arazi Kanunnamesinde yapılan bir düzenleme ile toprağın tapu bedeli erkek çocuklarda olduğu gibi kız çocuklarına da geçmesi sağlanmıştır (Oktar,1998 :20). Böylece kırsalda kadın miras hakkınıda elde ederek üretime tarlada, bağında çalışarak katılmaktadır (Altındal, 1994:50).

Osmanlı Devleti'nin ilk dönemlerinden itibaren şehir hayatında ticaret ve küçük çapta sanayiye dayalı olarak kadınlar eliyle üretim kollarının varlığı söz konusudur. Osmanlı kadınları vakıflardan dükkan kiraladıkları gibi mülkiyeti devlete ait olan çiftliklere ve devletin gelirleri arasında yer alan mukataaları iltizam yolu ile bazen malikâne divanı uygulaması yöntemi ile tasarruf hakkını elde ederek sahip oldukları mal varlıklarıyla yatırım yapmış ve kendilerine yeni gelir kaynakları elde etmişlerdir. Konuya ilişkin birkaç örnek vermek gerekirse; İstanbul Şeriyye sicili kayıtlarında(işs. Bab Mahkemesi, nr. 135, vr. 68b.1)“Dülbentci Hüsam mahallesinde, Emetullah Hatun vakfından icareteyn ile karısı Meryem'in tasarrufunda olan vakıf menzilin, tamamen yandığını ve karısının isteğiyle, kendine ait parayla, yeniden bina ettirdiğini" belirtmektedir. Başka bir belge de ise; (BOA, Hatt-ı Humayun, nr. 15962)vefat eden mumcular kethüdâsı Hacı Hüseyin'in Tekfur Sarayı ve sâir mahallerde olan mumhâne gediklerini irsen eşi Naile hanıma geçmiştir. Diğer bir belgede de(BOA, Cevdet, Evkaf, nr. 2173)Haftan Ağası'nın eşi Hafize Hâtun büyük Ayasofya Vakfı'ndan üç yumurtacı dükkânı hissesine mutasarrıftır. Hafize 
Hanım hac yolculuğunda vefat edince yumurtacı dükkânı hisseleri yedi yüz kuruşa açık arttırma ile talibine kiralanmışıı. Osmanlı kadınlarının yukarıdaki örneklerden anlaşılacağı üzere benzeri kazanç sağlayan bir çok işletmeye sahip olduklarını göstermektedir.

15. yüzyılın başlarında Osmanlı'da ipekçilik ve buna dayalı olarak dokumacılı̆̆ı ile öne çıkan ve ekonomi faaliyetlerin yoğun yaşandığı Bursa'da ticari faaliyette bulunan Araplar, İstanbul Yahudileri ve yerel tüccarlardan da bahsedilecek olunursa, bu dönemde Bursa ticaretinin boyutu Karadeniz ticareti de dahil olmak üzere italyan tüccarlarının elinden alınarak Osmanlı uyruklarının eline geçti ve 1450 ile $1480^{\prime} l i$ yıllar arasında ipekli dokumacılık alabildiğine genişledi (Faraqhı, 2008:103). Bu dönemde İş imkânlarının artması ve Osmanlı tebaası olmayan yabancı kimselerinde çalışmak için Bursa'ya göç ettikleri görülmektedir. XVI. Yüzyılın başlarında Osmanlı Devleti Akdeniz ülkeleriyle birlikte nüfus artışlarına sahne olmuş ve1520-1580 arasında bu nüfus artışı şehirlerdeki üretim artışıı da beraberinde getirmiştir (Koca, 1998:90). Bu yönüyle Bursa, Yabancı tacirlerin cazibe merkezi konumuna sahip olurken öte yandan da ipek dokumacılığı ve ticarette de önemli bir yere erişmiştir (Özbay, 2009:149-150). Bursa ipek sanayiinin hammadde açısından dışa olan bağımlılığı, siyasi olaylara da yön vermiştir. Nitekim Sultan I. Selim ile Safevi hükümdarı Şah İsmail arasında süren siyasi çekişmeler 1514'te ticareti durdurmuş ve 1518 'de ise iran ipeği çıkarılan bir ferman aracılı̆̆ı ile yasaklanmıştır (Faraqhı, 2008:104). Bunun üzerine kozacılık önem kazanmıştır. Kozadan başlayarak, ipliğin çekilmesi, bükülmesi, boyanması, ibrişim olarak işlenmesi, satışı ve dokunması dahil her aşamada çok ayıda kadın emeği kullanılmıştır (Oktar, 1998 :22-23).

Osmanlı kadını İstiglâl ${ }^{2}$ ve Mudârabe ${ }^{3}$ yöntemini de kullanmıştır. Osmanlı'da kadınlar zaman zaman vakıflardan ve şahıslardan gayrı menkûllerine karşıık istiglâl yöntemi ile kredi almışlar ve daha sonra borçlarını ödeyerek gayrı menkûllerini geri almışlardır. Öte yandan mudârabe yöntemi ile bir miktar parası olan kadınlar bâzen paralarını bir ortağa verip işletiyorlardı. 16. Yüzyılda Osmanlı Devleti'nde Şehirler ticaret ve hizmete dayalı olarak emeğin yoğun olduğu merkezlerdi. Dolayısıyla erkekler kadar kadınlarında şehirlerin sosyal ve ekonomik hayatında aktif oldukları görülmektedir. Özellikle kendi ürettiklerini pazarlarda yine kendileri satarak ihtiyacı olanı satın almaları ile ekonomik hayata canlıık katmışlardır.

\section{4. İ̧̧ Gücü Köle Kadın (Cariye)}

Ekonomi faaliyetler içerisinde yer alan menkul ve nakitten sonra emek gücünü oluşturan köle kadınlardı. Köle ve cariyeler alınıp satılabildiği gibi aynı zamanda miras da bırakılmıştır. Böylece bu statüdeki kadın önemli bir yatırım aracı haline geliyordu (Sahillioğlu, 1981:111-112) İpek dokumacııığının yaygın olduğu yine Bursa'da ipek ipliği, ipekli dokumada işgücünü Müslüman kadınlar ile köle kadınlar oluşturmaktaydı (Inalcık,1993:45). Örneğin; Bursa'da Yedi dokuma tezgahına sahip Hacı Bedrettin İshan'ın sekiz kadın kölesi vardı. Kadın emeğinin önemli bir yönü de kasabalarda ve bazı köylerde keten dokumacılığı ile öne çıkmaktadır (İnalıık, 1985 :27-29). 15. Yüzyılın ortalarında Haci Sinan isimli şahsın 6 dokuma tezgahı, 20 erkek ve 3 kadın köle çalışıırdığı görülmektedir. Bir başka belgede de 1500'lü yıllarda 1000 kadar ipekli dokuma tezgahı sahibi kadınlara ait iken, 1530 ve 1544 tarihlerinde ibrişim büken, 1574'te ise vale (bir cins ipekli kumaş) ustası kadınların adlarına rastlanmaktadır. (Dalsar, 1960:396; Oktar, 1998 :21). Dokumacılık yapan erkeklerden başka, bedenen çalışan kadın dokumacılar da vardı. İşi dokumacılık olan ve devamlı bu meslekle uğraşanların yanında, işi farklı olmasına

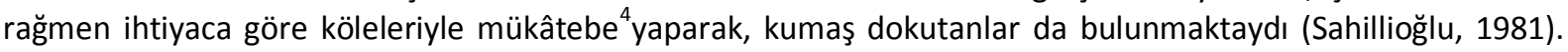
Anlaşmalı azatlık demek olan mükâtebegenellikle kölelerin sadakatle hizmetini sağlamağa yönelikti (Sahillioğlu, 1981: 67-138).

Osmanlı arşiv vesikalarında tespit edilen bir belgeye göre terekesinde köle bulunan tek hanım Rûhi Süleyman Ağa'nın eşi Emetullah Hanım'dır. Emetullah Hanım'ın ikisi bâkire üç Çerkez câriyesi vardır. Câriyelerin toplam bedeli 3870 kuruştur (Baş, 2006:75). Terekeler ile ilgili yapılan bir çalışmada cariye sahibi erkeklerin yanı sıra 2 Müslüman kadının da köle sahibi olduğu tespit edilmiştir. (Öztürk, 1994:201) Osmanlı Devleti'nde kölelik, genel itibariyle ev hizmetlerinde çalıştırılmak şeklinde yaygındı.

\footnotetext{
${ }^{2}$ Emlâk ve akarı borcuna karşıık alacaklıya bırakmak yahut gayrı menkûlünîrâdını borca karşı terk ve tahsîs etmek.

${ }^{3}$ Bir taraftan sermaye diğer taraftan emek ve çalışma üzerine kurulan bir ortaklık çeşidi.

${ }^{4}$ Anlaşmalı olarak işi tamamladığında azâd edilmek üzere bir bedele bağlanan köle.
} 
Ancak, imalathane sahipleri için ekonomik bir değer olarak görülmüştür. Kadın köleler, söz konusu olduğunda cariye olarak nitelendirilmişlerdir. Yukarıda da dile getirildiği gibi Mükâtebe uygulaması ticari anlayışa uygun olduğu bir zamanda köle sahibinin kölesi ile anlaşma yapmak, hem yatırımını değerlendirmek, hem de devamlı teşvik edilen azatık için iyi bir yoldu. kölenin beklediği ise, özgürlüğüne bir an önce kavuşmaktı. Anlaştığı işi bitirdiği takdirde özgürlüğüne kavuşuyordu (Özbay, 2009:155).

Osmanlı Kadınının miras aldığı, miras bıraktığı, borç aldığı, borç verdiği, emlâk alıp sattığı, vakıf kurduğu ve yönettiği yukarıdaki açıklamalardan anlaşılmaktadır. Osmanlı kadınının hem şehirlerde ve hem de kırsalda kadın hastalıklarını tedavi etme, doğum yaptırma ve benzeri meslekleri icra ettiği de görülmektedir. Ev işlerini yapmak ve çocukların eğitimiyle ilgilenmek de Osmanlı kadınının ana sorumlulukları arasındadır. Bu açıdan bakıldığında Osmanlı kadınının devletin kurulduğu andan itibaren ekonomik rolü tartışma götürmez (Dulum, 2006 : 55).

\subsection{7. ve 18. Yüzyılda Osmanlı Kadının Ekonomik Faaliyetleri}

17.yüzyıla gelindiğinde Müslüman kadınların ekonomik alanda etkinliğinin meslek ve hizmet bakımında arttığı görülmektedir. Şehirde yaşayan kadınların her ne kadar memur statüsünde bir konuma sahip olmasalar da, aile mirası olan gayrimenkulün işletmeciliğini üstlenmek suretiyle ekonomiye katkı sağladıkları daha önce de dile getirilmişti.

Bu devirde kadınlar, 1240 'da Anadolu'da faaliyet gösteren "ahilik" ve 1727'de "gedik" adını alan esnaf ve sanatkar kuruluşlarının (Gürol, 2000, 246) bir parçası olmasalar da evde imal ettiği ürününü, aracıya ihtiyaç duymadan çarşı-pazarlarda satabilmişlerdir. Şehir ve kırsal alanda bulunan "Avrat pazarı"olarak isim yapan bu alışveriş yerleri, sebze ve meyve gibi tarımsal ürünlerin yanında hayvansal ürünleri ve kadınların kendi yaptıkları el işlerinin satışa sunulduğu yerlerdi. Hürrem Sultan'ın desteği ile kurulan Haseki Darüşşifa ve İmaretinin yakınlarında bulunan söz konusu Pazar en yoğun olanı idi. Kadınlar burada hem alıcı hem de satıcıdır (Dingeç,2010 :13). Osmanlı kadınını tasvir etmek bakımından önemli bir göstergede servet sahibi Müslüman kadınların terekelerinde menkûl, gayrı menkûl mallarının dökümünde kullandığı ev eşyasından ziynet eşyasına kadar her şey kayıt altına alınmışır. Bu kayıtlar arasında okudukları kitaplarda bulunmaktadır. Osmanlı kadınlarının bilhassa ümera (yönetici) sınıf veya saray mensuplarının eşleri kitap okudukları anlaşılmaktadır. Örneğin, Rûhi Süleyman Ağa'nın zevcesi Emetullah Hanım'ın terekesinde de Kur'an-ı Kerim bulunmakla beraber Yâsin Tefsiri, falnâme, inşâ, dîvân, eflak-şems ve kamer adlı bir kitap, şahnâme, tabirnâme, Bâkî Dîvânı, Delâil-i Şerîf, Enâm-ı Şerîf ve bir dîvân ile birlikte on üç kitabın adı kayıtıdır. Bu kitapların maddi değeri 11089 kuruştu (Baş, 2006:81).

Osmanlı toplumunda kadınlar daima üretim ve ticaretin içinde bulunurken, arz ve talep durumuna göre bilhassa şehirli kadınların ürettikleri gibi tüketime de önem vermişlerdir. Özellikle saraylı kadınların üretimden çok tüketime yöneldikleri gözlenmektedir. Ihtiyaç duydukları malları bohçacı olarak tabir edilen kadınlar eliyle sağlarlardı. Bohçacıkadınlar, mahallelerde kapı kabı dolaşarak yatak, çarşaf, çeşitli kumaşlar, incik boncuksatarlardı. Kadın olmaları nedeniyle rahatlıkla hareme girer, hanım ve cariyelere satışyaparlardı (Tokmakçıŏlu, 1991 : 42). Osmanlı kadınları hiç kısıtı bir hayat içerisinde değillerdir. Elizabeth Cooper bu konuda; "Kadınların kelimenin hiçbir manasında tutsak olmadıkları gibi, kimi zaman bazı kişilerin bizi inandırmak istediklerinin tersine, kafesli pencerelerin ardından çıkmak için can atıyor da değillerdir. Bu mahremiyet hali Müslüman kadına ağır gelmez, hatta mahremiyetinin bozulması herkesten önce onu kızdıracaktır, çünkü böyle bir şey onun kocasının gözündeki kıymetini kaybettiği anlamına gelir" diyerek Osmanlı kadının ciddiyetini ve hassasiyetini tanımlamaktadır (Sancar, $2010: 37$ ).

Muhtemelen Osmanlı haremi üzerine yazılar kaleme alan yabancı seyyahların bohçacı kadınların dile getirdiklerinden yola çıkarak harem hakkında bir takım tanımlamalar ortaya koymuş olmalılar.

Burada altı çizilmesi gereken, Osmanlı toplumunda şehirli olsun kırsalda yaşayan kadın olsun her şeyi ile mükemmeldi denilemez. Çünkü, Kırsalda Kadın ailesi ile birlikte bağ-bahçe, tarım ve hayvancılıkla ilgili bedenen çalışırken, şehirlerde yasayan ve evine bakmak zorunda kalan bir kadın için hayat zordu. İş bulabileceği alan genelde ev hizmetçiliğiydi. Ev hizmetçiliğinde ise insan kaynağı genellikle kölelerden sağlanmaktaydı. Özgür ana-babanın çocuklarının köleleştirilmeleri yasak olduğundan Osmanlı tebaasından bir kadının iş bulması da zorlaşıyordu. Kadınlar, Osmanlı iş piyasasında yeterli iş olmaması veya istediği şartlarda kendine uygun çalışma bulmadığı zamanlarda da işsiz kalmakta idi. İş buluncaya kadar bazı kadınların ihtiyaçları vakıflar eliyle 
giderilmekte idi. Ancak burada iş ihtiyacı olan veya muhtaç durumdaki kadınların tümünün vakıflar eliyle intiyaçlarının karşılandığı söylenemez. Kimi kadınların Çukurova'da, Ege ve Akdeniz'de tarım işçisi olarak çalışıkları görülmektedir (Dulum, 2006 : 56).

\subsection{Tanzimat ve Sonrasında Kadın}

19. Yüzyılda Batı'da Sanayi devrimi ile hizmet sektörü çeşitlendi ve hizmet sektörüne ekonomik bir değer kazandırdı. Osmanlı devletinin ilk yıllarında kadınların zaviyelerde gelip gidenlere hizmet ettiklerini kolayca tespit edebiliyoruz. Ahi tekke ve zaviyelerinde misafir olarak barınanları kadınlar ağırlamışlardır. Nitekim döneme ilişkin kayıtlarda $\mathrm{Kız} \mathrm{Bacı,} \mathrm{Ahi} \mathrm{Ana,} \mathrm{Sakari} \mathrm{Hatun,} \mathrm{Hacı} \mathrm{Fatma} \mathrm{gibi} \mathrm{zaviye} \mathrm{adlarının} \mathrm{kadın} \mathrm{adları} \mathrm{ile}$ anılması ve kadınların bu gibi yerlerde hizmet sunduklarını göstermektedir (Koca, 1998:96).

Sanayileşme çabaları ve yeni iş imkanlarının ortaya çıkmasıyla birlikte çalışan kadınların toplumdan beklentileri ve ihtiyaçları arttı. Tanzimat ve II. Meşrutiyet dönemlerinde de bu ihtiyaçlarının karşılanması daha somut beklenti ve çabalara dönüşmüştür. Daha önceden geleneksel olarak her hangi bir eğitim almadan ampirik yöntemlerle yapılan mesleklerden söz edilmişti. Bu dönemde de kurumsal olarak kızların ebe ve öğretmenlik mesleklerine yönlendirilmesine çalışılmıştır. İki yıllık bir eğitimden sonra 1845 'de 36 kadından 10 Müslüman kadın ebelik diploması almıştır. Kadınların ücretli iş̧̧i olarak çalışmaya başlamaları daha öncede ifade edildiği üzere sanayi devrimin doğmasıyla başlar ve toplum hayatında belirgin hale gelir (Oktar, 1998:34).

19. yüzyılın ilk yarısında itibaren Osmanlı sanayisinde yaşanan gelişmeler Müslüman kadınların ekonomik faaliyetlerini yakından etkilemiştir. Anadolu'da ve Rumeli şehirlerinde ve kırsalında kadınlar ev tezgahlarında gömlek dokurlardı. Hatta büyük şehirlerin kibar konaklarına tezgahlar konup kız ve hanımları gömlek, don, çarşaf dokutmak için yevmiye ile çalıştııırlardı. Bez, gömlek, don, takye, çarşaf, çorap, mintan, yaygı perde gibi melbûsat ve mefrûşat böylece dışülkelerden ithal edilmezdi. Genelde ihtiyaç duyulan ürünler evlerdeki yahut çarşıdaki tezgahlarda dokunur ve çoğu kez kadınlar kendileri satar, evin bütün ihtiyaçlarını gidermek üzere erkeğine yardımcı olurdu (Özbilgen, 2010:464). Bazen de kadınlar tarafından dokunan kumaşlar Osmanlı Devleti'nin hemen her tarafında çullah esnafları tarafından bezastan denilen mekanlarda satıı ırdı (Koca, 1998:135).

19. yüzyılın ikinci yarısından itibaren Anadolu'nun birçok şehrinde evde yün dokuyan kadın sayısı toplam sekiz bine yaklaşıyordu. İzmir'deki el tezgâhlarında 3.500 kadın, 750 kız çocuğu halı dokuyordu (Oktar,1988). 19.Yüzyılın ortalarından itibaren elişleriyle ilgilenen, dokuma tezgâhlarının başında oturan kadınlar, artık fabrika işçisi sıfatıyla ekonomik faaliyete katıldılar. Yüzyılın sonlarına doğru Osmanlı Devleti'nde iplik eğirilen birkaç fabrika kuruldu. Ucuz kadın emeğinden yararlanan bu Osmanlı fabrikaları ingiltere, Belçika ve italya ve Hindistan üreticileriyle rekabet etme başarısını göstermiştir. 1850'de ve sonrası süreçlerde Osmanlı sanayileşmesinde önemli bir girişim olarak kabul edilen Bursa İpek Fabrikası da kapılarını kadınlara da açınca bu fabrikalarda çalışan kadın iş̧̧i sayısında önemli bir artış olmuştur (Quataert ve Zürcher,1998: 61).

Zamanla meydana gelen sosyal şartlar Osmanlı kadınını farklı çalışma alanlarına da itmiştir. Karşılaşılan bazı özel durumlar nedeniyle Osmanlı yönetimi kadın eleman çalıştırma yönünde yeni bir uygulama yapmak zorunda kalmıştır. Örneğin, hükümet tarafından sürgün cezasına çarptııılan kadın mahkûmlara sürgün yerlerine götürülene kadar eşlik etmeleri maksadıyla "Kadın Çavuş"lar vazifelendirilmiştir. Yine benzer bir örnekte "Trabzon RûsumatNezareti”ne yapılan bir ihbarda Osmanlı vapurunda yolculuk yapan dört kadının özel eşyaları arasında tabanca ve çeşitli miktarlarda kurşunların bulunduğu tespit edilmiştir. Bu ihbar üzerine yetkili makamlar, bu duruma sebep olan kadınların üzerinin kolcular tarafından aranmaması olarak gösterilince "bir kadın kolcunun gümrüğe atanması ivedilikle" istenmiştir. Bunun üzerine Padişah İradesi çıkmış ve Trabzon Gümrüğü’ne bir "Kadın Kolcu" atanmıştır. Bu görevliye aylık 250 kuruş maaş verilmek üzere üç bin kuruş bütçeye tahsisat ayrılmıştır (Oktar, 1998 : 58-59). Muhtemelen, ilk kez böyle bir uygulama ile Müslüman kadının Osmanlı idaresinde resmi görevli olarak atandığını göstermektedir.

\subsection{II.Meşrutiyet Döneminde Kadın}

II. Meşrutiyet döneminde Osmanlı Devleti'nin yoğun olarak yaşadığı savaşların etkisiyle ekonomik sorunlar ve yabancılara daha önceki dönemlerde kapitülasyonlar ile sağlanan kolaylıklar zamanla Osmanlı Devleti'ni dışarıya bağımlı hale getirmişti. Bu bağımlılığa karşı milliiktisat olarak da ifade edilen ekonomik anlayış gazete, dergi ve 
kitaplarda sık sık yer almakta idi. Kadınlar da konu ile ilgili düşüncelerini hem yönetici hem de yazar olarak yayınladıkları Kadınlar Dünyası Dergisi ile toplumu aydınlatmaya çalışılardı. Uzun süren savaşlar ekonomik maliyetleri oldukça artırmış ve iş gücü açığı ortaya çıkmıştı. Amaç, Ülke ekonomisini canlandırmak için kadınların bu açığı kapatması ve aynı zamanda iş hayatına dahil olmalarıydı ( Dulum, 2006: 60)

II. Meşrutiyet Dönemi Eğitim seviyesinin yükselmesi, dönemin aydınlarının kadın hareketlerine verdiği destek ve zamanla sağlanan ortamlar kadınların daha aktif olmasını ve çeşitli iş kollarında yer almasını sağladı. Osmanlı kadını sanayi iş̧̧isi olarak da önemli bir işleve sahipti. 1897 yılında İstanbul'daki kibrit fabrikasında çalışan 201 işçinin 121'i kadındı. Bakırköy bez fabrikasında çalışanların yarısını kadınlar oluşturuyordu (Gürol, 2000, 246).

1917 'de yapılan bir istatistiğe göre resmi dairelerde, ticarethanelerde ve çeşitli hizmetler veren özel işletmelerde çalışan kadın sayısı 1000'e yaklaşmıştı.1913 ve 1915 yıllarında ilk kez yapılan sanayi sayımlarında, işçi statüsünde çalışanların 1/3'ünü kadınların oluşturduğu tespit edilmiştir (Aydın, 1999, 73).

1918'de isstanbul Postanesi'nde çalışan Müslüman kadın sayısı 852'ye ulaşmıştı. Ancak Savaş yıllarında erkeklerini cepheye yollayan kadınların yaşam koşulları her geçen gün daha da zorlaşıyordu. Müslüman kadınların karşı karşıya kaldığı ekonomik sıkıntılardan büyük rahatsızlık duyan Harbiye Nazııı Enver Paşa, bazı toplumsal önlemler alma ihtiyacı hissetmiş olacak ki; "Kadınları Çalışırma Cemiyet-i i̇slamiyesi"ni kurdu(BOA, Dahiliye Nezareti Kalem-i Mahsus Evrakı, Dosya No: 42 Gömlek No: 10). Bu cemiyet Eşi Naciye Sultan'ın himayesi altında merkezi i̇stanbul'da olmak üzere çeşitli şehirlerde şubelerini açarak önemli faaliyetlerde bulundu. Kadınların çoğunlukla iş sahibi olduğu ve kazanç elde ettiği alanlar, dokuma ve gıda sektörüdür. Kadın derneklerinin desteği ile biçki ve dikiş çıraklık merkezleri faaliyete geçmesiyle meslek edinen kadınlar, konfeksiyon atölyelerinde kolayca iş bulabiliyor, özellikle göç eden Rum ve Ermeni kadın işçinin yerine işe giriyorlardı. Bu dönemde faaliyet alanı genişleten "Kadınları Çalışırma Cemiyet-i İslamiyesi" bir iş ve iş̧i bulma kurumuna dönüştü. intiyaçlar yoğunlaşınca Meclis-i Vükelâ’nın kararı ile çeşitli kuruluşlarda istihdam edilmek üzere mağdur olan yetim ve dul kadınlara da iş bulma imkanı sağlanmıştır.

Osmanlı'da kadınlar, maden işçisi olarak da çalışmıştır. 1915 yılı sanayi sayımı sonuçlarına göre, çeşitli sektörlerde kadın işçilere ödenen gündelikler, erkek iş̧̧ilere ödenenlerin yarısı kadardır. Kadınlar daha öğretmenlik, hemşirelik gibi mesleklerde yoğunlaşmışlardır (Doğramacı, 1997 : 21). Yukarıda da ifade edildiği gibi, en eski mesleklerden biride ebelikti. Osmanlı toplumunda genel olarak doğumlar evlerde ampirik bilgi ve deneyimlere sahip kadınların yardımıyla yapılmaktaydı. Ebeler pek çok doğumda bulunduklarından bazı manipülasyon tekniklerine sahiptirler. Ebelik hizmetleri yanında lohusalıkla ilgili koca karı ilaçları da düzenlerler. Osmanlı toplumunda ebelik mesleğinin tıbbi bir görünüm kazanması ancak 1827 de açılan "Tıphâne-i Âmire" de verilen cerrahiye dersleri içinde ele alındı. 1848 yılında da ruhsat nameli ebeler mezun edildi (Özbilgen, 2010 : 464).

Osmanlı'nın ekonomik yaşamında kadınların toplumda îfâ ettiği bazı meslekler, kadınlara hem gelir sağlamış hem de toplumsal hayatın aktif özneleri olmalarına imkân vermiştir. Açıkça belirtmek gerekirse Osmanlı toplumunda kadın belli sektörlerde ağırlıkı olmak kaydıyla sanılanın ötesinde girişimci ve üretici olarak ekonomik hayatın her alanında yeri almıştır.

\section{SONUÇ}

Osmanlı toplumunun takriben nüfusunun \%90'nına yakını kırsalda yaşamaktadır. Bu bakımdan Ekonomik hayat kırsalda büyük ölçüde tarım ve hayvancılığa dayanmakta idi. Kırsalda erkeklerle birlikte aktif rol üstlenen kadınlar, ailenin mali intiyaçlarına katkıda bulunacak çeşitli faaliyetlerde bulunuyorlardı. Bu ekonomik faaliyetleri ev işlerinden küçük çapta dokuma, boyama, bağ-bahçe işleri, tohum saklama ve üretimi geliştirmeye yönelikti. Şehirde yaşayan kadınlar ise ürettikleri malları pazarda satma, dükkân işletmek, ebelik, çamaşırhane işletme gibi faaliyetleri yanı sıra, köle ticaretiyle uğraşan, vakıf yöneticisi ve gayrimenkul alım-satımı ile uğraşan kadınların olduğu da Başbakanlık Osmanlı Arşivinde yer alan vesikalardan tespit edilebilmektedir.

17. yüzyıl tereke defterleri üzerinde yapılan incelemeler, kadınların üçte birinin ev sahibi olduğunu göstermiştir. Şehirlerde atölye sahibi hanımlara rastlanmıştır. Bursa ipekli sanayiinde üretim yapan tezgâhlardan üçte birinden fazlası kadınlara aittir. Her ne kadar loncalara üye olmasalar da, Kadınlar bilhassa tekstil alanında ürettikleri ürünlerini çarşı ve pazarlarda satarak ticaret faaliyetinde bulunmuşlardır. Kadınların tereke 
defterlerinde görülen mal varlıkları kendilerine gelir getirecek ekonomik bir faaliyette bulunduklarının göstermektedir. Osmanlı ekonomisinde "mudarebe" diye bilinen, ticarette belli bir oranda kâr alma esasi üzerine, sermaye vererek ticarî ortak olan kadınlara rastlanmıştır.

Osmanlı Devleti'nde mükatebe yöntemi ile köle kadınların çalıştıııldı tespit edilmektedir. Kölelik, genel itibariyle ev hizmetlerinde çalıştııımak şeklinde yaygındı.

Osmanlı toplumunda tarım sektörünün dışında bilhassa şehirde yaşayan ve mali imkanlara sahip olan kadın, miras aldığı, miras bıraktığı, borç aldığı, borç verdiği, emlâk alıp sattığı, vakıf kurduğu ve yönettiği. Osmanlı kadınının hem şehirlerde ve hem de kırsalda kadın hastalıklarını tedavi etme, doğum yaptırma ve benzeri meslekleri icra ettiği de görülmektedir.Ev işlerini yapmak ve çocukların eğitimiyle ilgilenmek de Osmanlı kadınının ana sorumlulukları arasındadır. Bu açıdan bakıldığında Osmanlı kadınının devletin kurulduğu andan itibaren ekonomik rolü tartışma götürmez.

\section{KAYNAKLAR}

Başbakanlık Osmanlı Arşivi (BOA)

Tahrir Defterleri (TD) :

BOA.TD. 149 :257-342.

BOA.TD.232 : 287-383.

Arşiv Vesikaları:

BOA, Cevdet, Maliye, nr. 18496.

BOA, Cevdet, Adliye, nr. 1873.

BOA, Cevdet, Maliye, nr. 21350.

BOA, Cevdet, Maliye, nr. 11427.

BOA, Hatt-ı Humayun, nr. 15962.

BOA, Cevdet, Evkaf, nr. 2173.

BOA, Dahiliye Nezareti Kalem-i Mahsus Evrakı, Dosya No: 42 Gömlek No: 10.

BOA, Hatt-ı Hümâyûn, nr. 14853.

Şer'iye Sicilleri, I ve II, Türk Dünyası Araştırmaları Vakfı, İstanbul, 1989.

İstanbul Şeriye Sicili; işS. Bab Mahkemesi, nr. 135, vr. 68b.1.

Yayınlanmış Eserler :

Akyılmaz, G. (2002), Osmanlı Aile Hukukunda Kadın, Türkler, Yeni Türkiye Yayınları, C.10, Ankara, 365-374.

Altındal, M. (1994), Osmanlıda Kadın, Altın Kitaplar Yayınevi, İstanbul.

Aydın, M. O. (1999), "Yasal Açıdan Kadın İşgücü,” Türkiye'de Kadın İşgücü Seminerleri, 1-2, TísK Yayınları, Yay. No. 192.

Aysu, A. (2009), Piyasa ve Küçük Köylülük. Mülkiye Dergisi, Bahar, 223-237.

Barkan, Ö.L.(1953), “Tarihi Demografi Araştırmaları ve Osmanlı Tarihi”. Türkiyat Mecmuası X: 1-26.

Baş, E. (2006), Arşiv Belgelerinden Hareketle XVIII. Y. Y. Osmanlı Toplum Hayatında Kadın, Marmara Üniversitesi, Sosyal Bilimler Enstitüsü, Yüksek Lisans Tezi, İstanbul.

Dalsar, F. (1960), Türk Sanayi ve Ticaret Tarihinde Bursa'da İpekçilik, İstanbul Üniversitesi İktisat Fakültesi Yayınları, No. 116, İstanbul.

Dingeç, E. (2010), Osmanlı Toplumunda Kadınların Üretime Katkıları, HistoryStudies, 2/1, 9-30.

Doğramacı, E. (1997), Türkiye'de Kadının Dünü ve Bugünü, Türkiye İş Bankası Yayınları. No.300, Sosyal Felsefi Dizi:31, Doğuş Matbaacılık, Ankara,

Dulum, S. (2006), Osmanlı Devleti’nde Kadının Statüsü, Eğitimi ve Çalışma Hayatı (1839-1918), Osmangazi Üniversitesi, Sosyal Bilimler Enstitüsü, Yüksek Lisans Tezi, Eskişehir.

Ecer, V.A. (2012), Tarihte Lider Kadınlar ve Fatma Bacı, İstanbul.

Faraqhi, S. (2008), Osmanlı Dünyasında Üretmek, Pazarlamak, Yaşamak, YKY, İstanbul. 
Gerber, H. (1980), "SocialandEconomicPosition of Women in the an Otoman City, Bursa, 1600-1700", IJMES, cilt 12, s.231-244.

Gerber, H. (1998), "Bir Osmanlı Şehri Olan Bursa'da Kadının Sosyo-Ekonomik Statüsü (1600-1700)", çev. Hayri Erten, Selçuk Üniversitesi ilahiyat Fakültesi Dergisi, (sayı:8), 327-343

Gürol, M. A.(2000), Türkiye' de Kadın Girişimci ve Küçük İşletmesi. Atılım Üniversitesi Yayını, Ankara.

Inalcık, H. Ve DonaldQuataert, (1994),An EconomicandSocialHistory of theOttomanEmpire1300-1600, C.1, Cambridge UniversityPress, Cambridge.

İnalcık, H. (1985), ServileLaborStudiiesTheOttomanSocialAndEconomicHistory, RiceCultivation in theOttomanEmpire, London.

Inalcık, H. (1998), " Çiftliklerin Doğuşu: Devlet Toprak Sahipleri ve Kiracılar", Osmanlı'da Toprak Mülkiyeti ve Ticari Tarım, ed. Çağlar Keyder, Faruk Tabak, Tarih Vakfı YurtYayınları, İstanbul, s.17-35

İnalcık, H. "Bursa: XVI. Asır Sanayi ve Ticari Tarihine Dair Vesikalar”, Osmanlı İmparatorluğu Toplum ve Ekonomi, Eren Yayınları, İstanbul 1993.

İslamoğlu, H. (2010). Osmanlı İmparatorluğu’nda Devlet ve Köylü, İletişim Yayınları, İstanbul.

Jennings, R. C. (1975), "Women in Early17th Century Otoman JudicialRecords-TheSharia Court Of Anatolian Kayseri" , Journal of theEconomicAndSocialHistory Of The Orient, Vol: XVIII, Part:1January, s.53-114.

Koca, K.Y. (1998), Osmanlı'da Kadın Ve İktisat, Beyan Yayınları İstanbul.

Köksal, H. (2010), Rivayetler Işığında Hz. Peygamber Döneminde Gündelik Hayat Ve Kadın, Ankara Üniversitesi, Sosyal Bilimler Enstitüsü, Basılmamış Yüksek Lisans Tezi, Ankara.

Oktar, T. (1998), Osmanlı Toplumunda Kadının Çalışma Yaşamı, Osmanlı Kadınları Çalıştırma Cemiyet-i İslâmiyesi, Bilim Teknik Yayınevi, İstanbul.

Özbay, R.D. (2009), “Osmanlı İmparatorluğu’nda Köle Emeğinin İstihdamı ve Mükâtebe Yöntemi”, Kocaeli Üniversitesi Sosyal Bilimler Enstitüsü Dergisi (17) 2009 / 1 : 148 - 163).

Özbilgen, E.(2010), Bütün Yönleriyle Osmanlı Âdâb-ı Osmâniyye, İstanbul 2010.

Özer,M. ve Biçerli, K. (2004). Türkiye’de Kadın İşücünün Panel Veri Analizi, Sosyal Bilimler Dergisi, 55-85.

Öztürk, S. (1994), İstanbul Tereke Defterleri (Sosyo-Ekonomik Tahlil), Osmanlı Araştırmaları Vakfı, İstanbul.

Pamuk, Ş. (1990), Osmanlı-Türkiye İktisadî Tarihi 1500-1914, İstanbul.

Sahillioğlu, Halil (1981). "Onbeşinci Yüzyılın Sonu ile Onaltıncı Yüzyılın Başında Bursa’da Kölelerin Sosyal ve Ekonomik Hayattaki Yeri”, 19791980 Özel Sayısı, Ankara: ODTÜ Gelişme Dergisi: 67-138

Sancar, A. (2010), Osmanlı Kadını Efsane ve Gerçek, Kaynak Yayınları, İzmir.

Selmin Kangal ve vd.(1993) Çağlar Boyunca Anadolu'da Kadın, T.C.Kültür Bakanlığı Yay. Ankara.

Tokmakçıoğlu, E. (1991), Osmanlı Kadın Âlemleri, Geçit Kitabevi, İstanbul. 


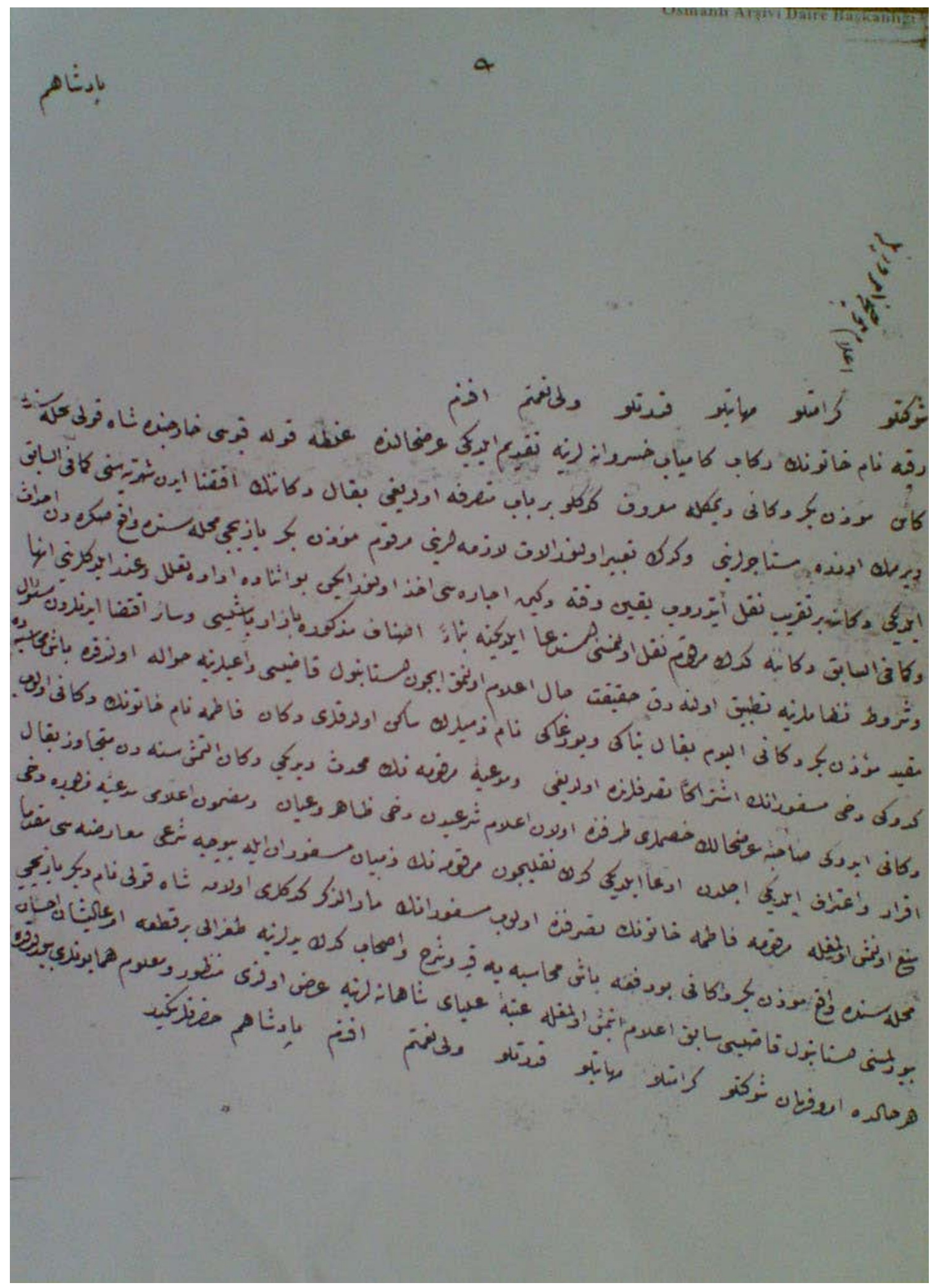

BOA, Hatt-ı Hümâyûn, nr. 14853, (1210 / 1795-1796) Galata'da Yazıcılar Mahallesi'nde bakkal dükkânı mutasarrıfı olan Fatma İsimli bir hanıma ait vesika. 


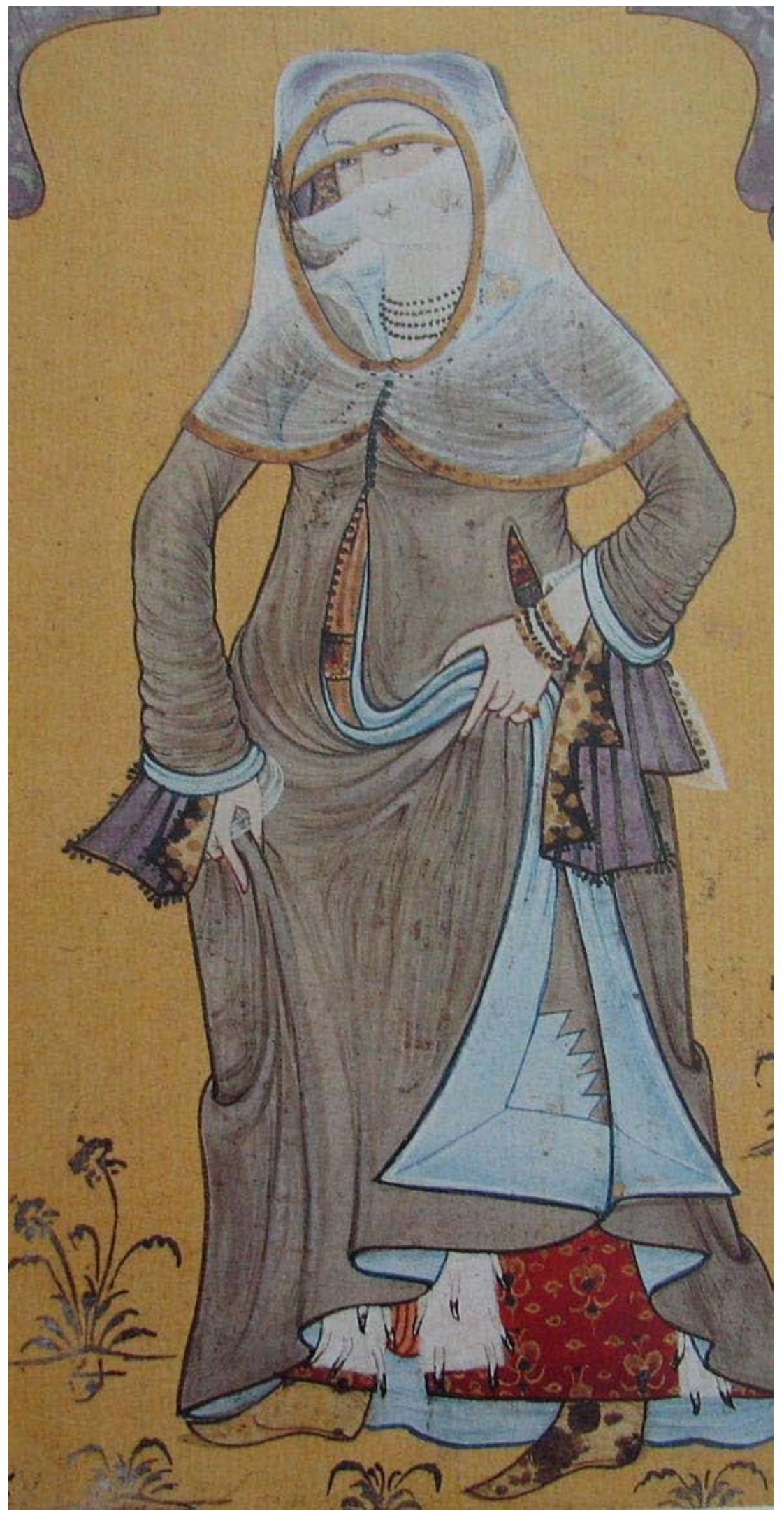




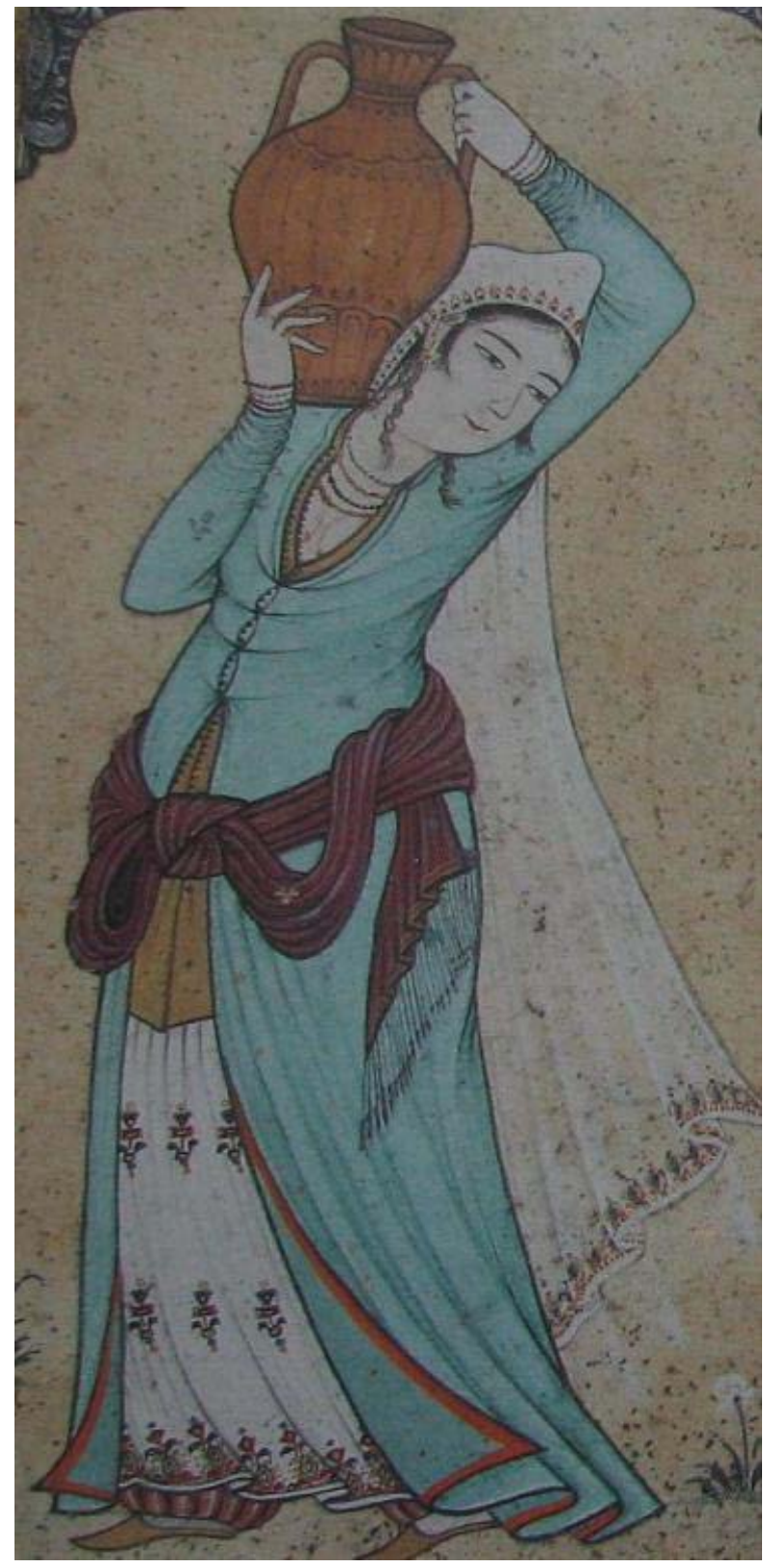

YukarıdaFerâceli Kadın ile su testisi taşıyan kadın Levnî imzalı 1720-1725) ${ }^{5}$

${ }^{5}$ Selmin Kangal ve vd, Çağlar Boyunca Anadolu'da kadın T.C.Kültür Bakanlığı Yay. Ankara 1993, s.215 